\title{
Effect of processing germinated shea kernels on the quality parameters of shea (Vitellaria paradoxa) butter
}

\author{
Jude U. Obibuzor*, Roland D. Abigor, Vivien Omoriyekemwen, Emmanuel A. Okogbenin and \\ Tonbra Okunwaye
}

Biochemistry Division, Nigerian Institute For Oil Palm Research (NIFOR), PMB 1030, Benin City, 300001 , Edo State, Nigeria.

Accepted 25 March, 2013

\begin{abstract}
The processing methods, kernel storage and phytosanitory conditions are some of the major challenges leading to production of low quality shea butter. The effect of processing germinated shea kernels on the overall quality of processed butter was examined. Shea fruits were picked under different shea trees, pooled, and divided into two portions: one portion was processed immediately; the other was germinated for 9 days. The butter expressed from the respective portions was analyzed using standard methods. The yield of the extracted butter from the germinated and ungerminated kernel was 52 and $49 \%$, respectively. The physicochemical properties of butter from the ungerminated and germinated nuts were free fatty acid (FFA) (0.22 and 1.66\%), saponification value (SV), (223 and $239 \mathrm{mg}$ $\mathrm{KOH} / \mathrm{g}$ ), unsaponifiable matter (7.77 and 9.39\%), iodine value (Wijs) (IV) (33 and 30), and peroxide value (PV) $(0.10$ and $8.14 \mathrm{meq} / \mathrm{kg})$, respectively. Germination process depleted the lipid content of shea kernel, and elevated the FFA by 7-folds, the PV by 81, while IV decreased. Again, germination mobilized linoleic acid more than the other constituent fatty acids, and the elemental composition remained generally unaffected. Prompt sterilization and sorting out the germinated kernels are necessary steps to improving the quality of shea butter.
\end{abstract}

Key words: Germinated shea kernel, butter quality, desaturation, fatty acids, elemental analysis.

\section{INTRODUCTION}

Shea tree (Vitellaria paradoxa) is one of the most important sources of vegetable oil in rural areas of the savanna zone of West Africa (Nikiema and Umali, 2007). Nigeria is the leading producer of seeds: $355,000 \mathrm{t}$ in 1999, 58\% of the African production, but 10,000 t lower than in 1996. Mali and Burkina Faso are other leading producers; at the end of the 1990s they produced 85,000 and 70,000 t/year, respectively, followed by Ghana Ghana $(55,000$ t), Côte d'Ivoire (20,000 t), Benin (15,000 t) and Togo (6500 t) (Nikiema and Umali, 2007). Contrary, Nigeria is correspondingly not the leading exporter of shea butter. Shea tree stores fat in the kernel of its seed. The approximate chemical composition of the kernel per $100 \mathrm{~g}$ dry matter, which varies considerably across the shea distribution region of West Africa (Okullo et al., 2010) is fat 31 to $62 \mathrm{~g}$, protein 7 to $9 \mathrm{~g}$, carbohydrate 31 to $38 \mathrm{~g}$, unsaponifiable matter 2.5 to 12 $\mathrm{g}$ (Nikiema and Umali, 2007). The kernels are processed into shea butter and pressed cake. Food processing in general involves synergism between different physical processes to transform raw animal/plant materials into consumer-ready products. In addition, consumers judge 
food quality based on the sensory and nutritional characteristics such as texture, flavour, aroma, shape, colour calorie content, vitamins as well as shelf life (Norton and Sun, 2008). Currently, the processors use three main methods namely, artisanal, mechanical and solvent, which have different extraction efficiencies, to extract shea butter from the kernel. Carette et al, (2009) had reported that the manual method is preferred by the processors although less efficient. This is because manual method was found to be more profitable compared to mechanized shea butter extraction due to the fuel cost, maintenance cost, and cost of the shea kernels that are involved with the mechanized process. In artisanal, for example, the first step is to break the kernels into small pieces using mortar and pestle. Then, these nut pieces are roasted, and when roasted, the pieces are pounded again with a mortar and pestle to obtain a brown-black paste. The roasted black paste is grinded with a grinding stone on a flat stone surface and beaten into paste with the addition of warm water to a desired consistency. This mass is then washed once or twice before boiling the creamy mass in a cooking pot to yield the butter. Shea butter is reputed to have wide range of applications in the pharmaceutical, cosmeceutical (AarhusKarlshamn, 2012), nutraceuticals, etc industries as well as in the folk medicine. The health benefits of the shea butter are attributed to the influence of the constituents of the unsaponifiable.

The quality of fats and oils is dictated by several physical and chemical parameters that are dependent on the source of oil; geographic, climatic, and agronomic variables of growth in the case of plant oils as well as processing and storage conditions (Shahidi, 2005). In the case of shea butter production, the fruits are collected from the ground but must not be allowed to stand for long on the ground as they germinate quickly. This is because the shea fruit has no dormancy period, it germinates within few days of dropping from the tree (Jøker, 2000). This means that is for high quality butter, prompt processing is an important requirement but currently neglected by the local processors due to the difficulties associated with fruit collection. The process of germination is capable of modifying the lipid composition by the endogenous enzymes leading to poor understanding of the state of the nut, prior to processing. The state of the plant materials prior to processing could affect or modify all or some of the food qualities parameters listed above besides other factors such as processing methods and conditions (Olaniyan and Oje, 2007). It has been reported that changes in the expression of various fatty acid metabolizing enzymes can result in changes in seed oil compositions (Napier, 2007; Knutzon, 1992). For example, the predominant offflavour perceived in some products made from soybeans comes from the activity of endogenous lipoxygenase enzymes found in soybeans (lassonova et al., 2009).

Germination process in seed sometimes may be a nuisance due to the depletion of the target reserves or a strategy to enhance some nutritive constituents of the seed. According to Munshi et al. (2007), the quantity of phospholipids, glycolipids and sterols in cotyledons and embryonic axes in fast germinating seeds increased progressively between the 1 to 6 days after sowing (DAS) compared with the slow growing seeds. The fatty acid composition in cotyledons of fast growing seeds showed increased levels of palmitic and oleic acids 6 and 8 DAS, while a decline in palmitic and stearic acids as well as accumulation of oleic and linoleic acids were observed in slow growing seeds. On the other hand, Urbano et al. (2004) studied the effects of germination of Pisum sativum L, for 2, 4 or 6 days, with and without light, on the proteolytic activity, the contents of soluble protein and non-protein nitrogen, and the amount of available starch of $P$. sativum $\mathrm{L}$. as well as their nutritive utilization by growing rats, and concluded that germination of peas for 2 days would be sufficient to significantly improve the palatability and nutritive utilization of protein and carbohydrates from $P$. sativum $\mathrm{L}$.

The timely picking of shea fruits from the bush is one of the most important steps in obtaining high quality butter ultimately. The picking activity requires contingent arrangement; it is tedious, and clumsy in addition to being a dangerous undertaking because the picking crews are constantly faced with some challenges such as snake bite, poor visibility, covering long distances, harassment by monkeys and other reptiles (Nahm, 2010). Because of these challenges associated with shea fruit collection, the processors insist on processing every kernel picked irrespective of its state (germinated) or integrity.

This present work seeks to evaluate the effect of processing germinated shea kernels on the quality of butter via physicochemical analysis.

\section{MATERIALS AND METHODS}

\section{Shea kernel}

Shea kernels were obtained from Bida, Niger State, the city is located at latitude $9.07459600(9428.55 \mathrm{~N})$, longitude 6.00850500 (6 $030.62 \mathrm{E})$ and elevation of $590 \mathrm{ft}$ above sea level, and is a semiarid town. Shea fruits $(20 \mathrm{~kg})$ were picked under about 10 trees in Bida, Niger State, Nigeria in July, 2012.

\section{Chemicals and reagents}

All the chemicals and reagents used in this study were of analytical grade (AnalaR). Shea fruits of about $13 \mathrm{~kg}$, were picked under 10 different shea trees within $500 \mathrm{~m}$ radius, and were pooled. The picked shea fruits were immediately transported in black polythene bags to Nigerian Institute for Oil Palm Research (NIFOR) Shea Tree Substation, Bida and divided into 2 portions. One portion was parboiled at $100^{\circ} \mathrm{C}$ for 90 min to stop the activities of endogenous enzymes during transportation to Benin City (about $9 \mathrm{~h}$ trip), while the second was not parboiled but allowed to germinate. The boiled fruits were allowed to cool and then manually de-pulped. The depulped fruits were spread on a wooden floor overnight before transporting to Biochemistry Division Laboratory where the extraction and characterization experiments were performed. The 


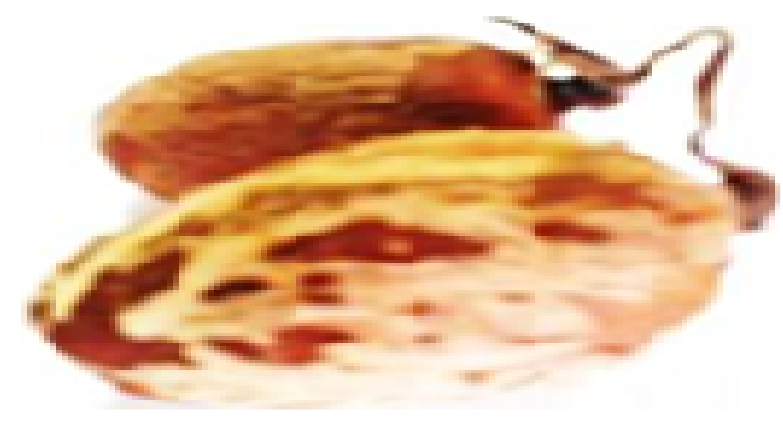

Figure 1a. Germinated shelled shea kernels.

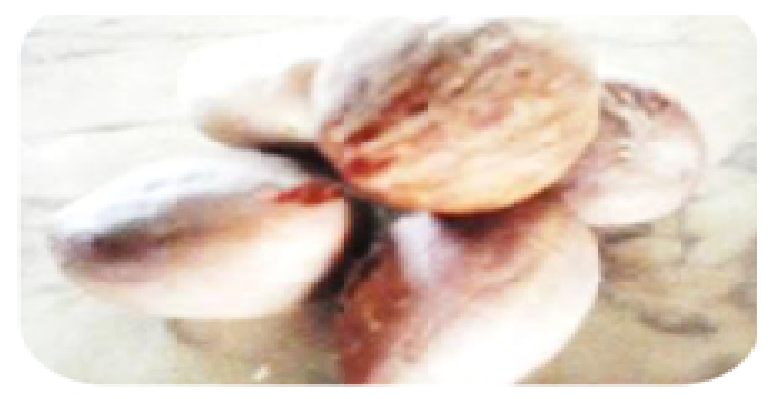

Figure 1b. Ungerminated shelled shea kernels.

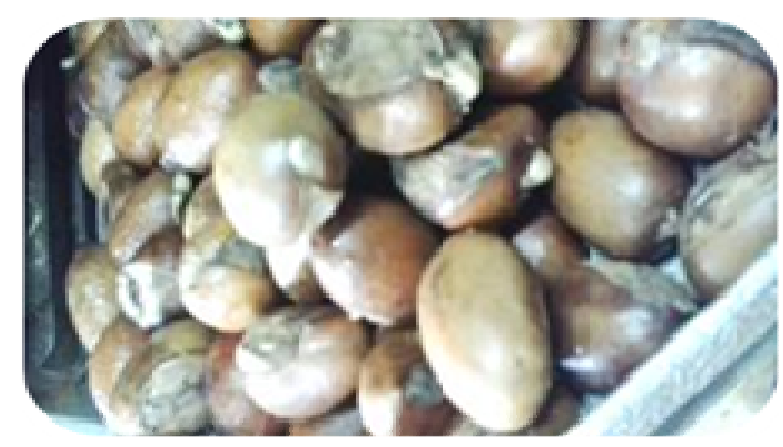

Figure 1c. Freshly germinated unshelled shea nuts.

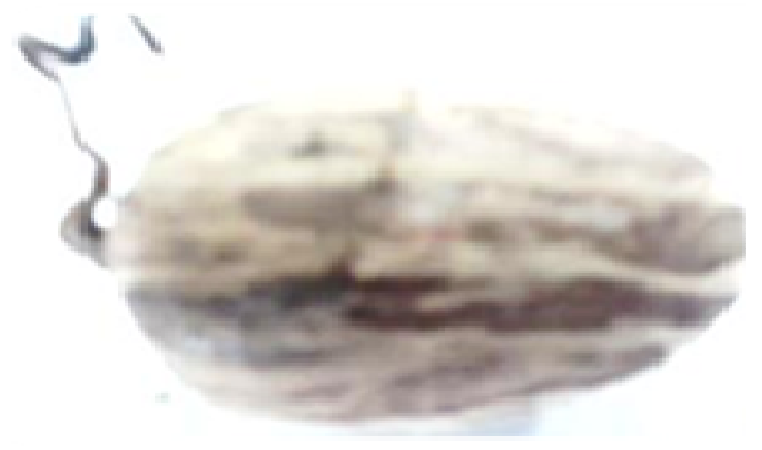

Figure 1d. Germinated shelled shea kernel showing dried radicle. unparboiled portion was heaped for 9 days behind Room 76 of Biochemistry Division building, NIFOR, Benin City at ambient temperature $29 \pm 3^{\circ} \mathrm{C}$ to induce germination(Figure 1a). The freshly germinated fruits (Figure 1c) $(5.85 \mathrm{~kg})$ were selected and, for the butter extraction treated exactly as the fresh ungerminated sample (Figure 1b).

Both the germinated and ungerminated fruits were respectively de-pulped and dried at $105^{\circ} \mathrm{C}$ in an oven (Gallenkamp Plus II, England) until it could be easily cracked (14 h). The dried nuts were cracked (shelled) manually (Figure 1d), and were further oven dried at $105^{\circ} \mathrm{C}$ for a total of $18 \mathrm{~h}$. Then, weighed portions of the dried nuts were processed into shea butter by respectively expressing the oil with a hand operated stainless expeller. The expressed oil was centrifuged at 3500 revolution per minute (rpm) to remove the artifact and debris to yield very clear golden yellow oil. The emphasis here was not on the yield of the oil but purity.

\section{Proximate analysis of the kernels}

Samples of kernels from each category were selected at random, pooled and examined for moisture, lipid, crude protein, nitrogen free extract (NFE) and ash contents. The moisture content was determined by AOCS method (AOCS, 1997). The shea kernels were milled with a blender (lexus, China) and oil extracted for $18 \mathrm{~h}$ with $96 \%$ pure $n$-hexane (Scharlau, Spain) in a soxhlet apparatus and the lipid percentage was computed by weight difference. Ash and nitrogen content were measured according to $A O A C$ methods 40.1.08 and 40.1.06, respectively (AOAC, 2010). The ash content was determined by heating the samples in a muffle furnace at $525^{\circ} \mathrm{C}$, cooled in a desiccator and weighed with an analytical balance. The protein content on the other hand was obtained according to the Kjeldahl method and converted to protein percentage by multiplying with the Atwater factor (conversion). NFE was quantified by difference: hundred minus the sum of percentage moisture, lipids, ash and crude protein. The elemental analysis of the pressed cake was carried out using the standard atomic absorption spectroscopy (AAS) and titrimetric methods.

The extracted butter samples (solidified on cooling) were respectively analyzed using the standard methods of analysis (AOCS, 1997) as follows: free fatty acid (FFA) (Ca-5a), moisture (Ca 2c-25), peroxide value (PV) (Cd 8 -90), saponification value (SV) (Cd-3-25), iodine value(wijs) (IV) (Cd 1-25), density(Cc10b -25), Lovibond colour (Cc 13e) unsaponifiable (UM) (Ca 6a 40) and panisidine Value (AnV) (Cd 18-90) and melting range (Cc 3-25). We computed total oxidation, Totox using (2PV+AnV).

\section{Statistical analysis}

We performed all chemical analyses in triplicate. The data generated were analyzed using the SPSS software version 17 . We computed the means and standard deviation and, performed the analysis of variance (ANOVA) $\mathrm{P}<0.05$ to find significant differences between means.

\section{RESULT}

Tables 1 and 2 respectively show the proximate composition of the kernels and the physicochemical characteristics of the expressed butter from the ungerminated and germinated kernels. Table 3 shows the fatty acid composition of the butter, while the result of the elemental analysis was presented in Table 4. 
Table 1. Proximate composition of different shea kernel (dry weight basis).

\begin{tabular}{lcc}
\hline Parameter (\%) & Germinated & Ungerminated \\
\hline NFE & $38.34 \pm 0.1^{\mathrm{a}}$ & $36.88 \pm 0.003^{\mathrm{b}}$ \\
Lipid & $48.87 \pm 0.03^{\mathrm{a}}$ & $51.52 \pm 0.05^{\mathrm{b}}$ \\
Protein & $10.34 \pm 0.04^{\mathrm{a}}$ & $8.58 \pm 0.02^{\mathrm{b}}$ \\
Ash & $2.95 \pm 0.02^{\mathrm{a}}$ & $3.10 \pm 0.01^{\mathrm{a}}$ \\
\hline
\end{tabular}

Rows with different alphabets are significantly different $(P<0.05)$.

Table 2. Physicochemical characteristics of the expressed shea butter.

\begin{tabular}{lcc}
\hline Parameter/Units & Ungerminated & Germinated \\
\hline FFA (\%) & $0.22 \pm 0.02^{\mathrm{a}}$ & $1.66 \pm 0.06^{\mathrm{b}}$ \\
SV (mg/KOH/g) & $223.33 \pm 0.58^{\mathrm{a}}$ & $239.0 \pm 2.0^{\mathrm{b}}$ \\
PV (meq oxygen/kg oil) & $0.10 \pm 0.02^{\mathrm{a}}$ & $8.14 \pm 0.59^{\mathrm{b}}$ \\
p-Anisidine value (meq oxygen/kg oil) & $0.03 \pm 0.11^{\mathrm{a}}$ & $3.17 \pm 0.21^{\mathrm{b}}$ \\
Totox & 0.23 & 19.45 \\
IV (wijs) & $33.06 \pm 0.57^{\mathrm{a}}$ & $30.29 \pm 0.4^{\mathrm{b}}$ \\
Density (g per ml) at $40{ }^{\circ} \mathrm{C}$ & $0.880 \pm 0.00^{\mathrm{a}}$ & $0.870 \pm 0.00^{\mathrm{b}}$ \\
Unsaponifiable matter (\%) & $7.77 \pm 0.07^{\mathrm{a}}$ & $9.39 \pm 0.03^{\mathrm{b}}$ \\
Moisture (\%) & $0.004 \pm 0.002^{\mathrm{a}}$ & $0.004 \pm 0.001^{\mathrm{a}}$ \\
${ }^{*}$ Melting range $\left({ }^{\circ} \mathrm{C}\right)$ & $32-33$ & $33-35$ \\
Colour (Lovibond 51/4"Cell) & 1.2 Red $^{\mathrm{a}} 13$ Yellow $^{\mathrm{a}}$ & 1.3 Red $^{\mathrm{a}} 12.4$ Yellow $^{\mathrm{a}}$ \\
\hline
\end{tabular}

Rows with different alphabets are significantly different $(P<0.05)$. ${ }^{*}$, Was not subjected to ANOVA analysis.

Table 3. Fatty acid composition of the butter extracted from the germinated and ungerminated shea kernel.

\begin{tabular}{lcc}
\hline Fatty acid (wt \%) & Ungerminated & Germinated \\
\hline Palmitic acid (C16: 0) & $5.89 \pm 0.02^{\mathrm{a}}$ & $5.88 \pm 0.04^{\mathrm{b}}$ \\
Stearic (C18:0) & $41.87 \pm 0.01^{\mathrm{a}}$ & $42.81 \pm 0.03^{\mathrm{b}}$ \\
Oleic (C18:1) & $45.12 \pm 0.03^{\mathrm{a}}$ & $44.20 \pm 0.02^{\mathrm{b}}$ \\
Linoleic (C18:2) & $5.34 \pm 0.04^{\mathrm{a}}$ & $3.65 \pm 0.03^{\mathrm{b}}$ \\
Linolenic (C18:3) & $0.94 \pm 0.04^{\mathrm{a}}$ & $0.40 \pm 0.07^{\mathrm{b}}$ \\
Arachidonic (C20:0) & $0.84 \pm 0.03^{\mathrm{a}}$ & $0.49 \pm 0.05^{\mathrm{b}}$ \\
Total & 99.47 & 98.57 \\
\hline
\end{tabular}

Rows with different alphabets are significantly different while rows with the same alphabets are not significantly different.

\section{DISCUSSION}

Shea tree is exploited because of its high content of solid fat (shea butter) stored in the kernel reserve. The reserves are mainly in the form of oil, protein, and starch in embryo or endosperm, and their relative amounts vary in different species (Ming-Feng et al., 2009). The seed germination and the subsequent seedling growth need large amounts of energy and nutrition, which can be provided only by seed reserves, because the germinating seed lacks a mineral uptake system and photosynthetic apparatus (Bewley, 1997). Therefore, any biochemical action or otherwise that tends to negatively affect the butter depletion or yield must be properly managed. Table 1 shows that germination process in shea kernel for a period of 9 days significantly modified the constituents of the kernel. The lipid content with respect to the ungerminated decreased from 51.52 to $48.87 \%$, the protein content increased from 8.58 to $10.34 \%$, while the NFE also increased in the germinated kernel. However, 
Table 4. Elemental composition of the pressed cake shea kernels.

\begin{tabular}{lcc}
\hline Parameter & Germinated & Ungerminated \\
\hline Calcium (\%) & $0.29 \pm 0.04^{\mathrm{a}}$ & $0.24 \pm 0.7^{\mathrm{a}}$ \\
Magnesium (\%) & $0.04 \pm 0.04^{\mathrm{a}}$ & $0.03 \pm 0.03^{\mathrm{a}}$ \\
Sodium (\%) & $1.2 \pm 0.1^{\mathrm{a}}$ & $1.68 \pm 0.00^{\mathrm{b}}$ \\
Potassium (\%) & $23.32 \pm 0.00^{\mathrm{a}}$ & $23.52 \pm 0.02^{\mathrm{b}}$ \\
Chromium (ppm) & $0.04 \pm 0.00^{\mathrm{a}}$ & $0.05 \pm 0.01^{\mathrm{a}}$ \\
Manganese (ppm) & $0.11 \pm 0.02^{\mathrm{a}}$ & $0.17 \pm 0.03^{\mathrm{a}}$ \\
Iron (ppm) & $3.37 \pm 0.82^{\mathrm{a}}$ & $2.20 \pm 0.4^{\mathrm{a}}$ \\
Cobalt (ppm) & $0.03 \pm 0.01^{\mathrm{a}}$ & $0.03 \pm 0.01^{\mathrm{a}}$ \\
Nickel (ppm) & $0.06 \pm 0.03^{\mathrm{a}}$ & $0.07 \pm 0.04^{\mathrm{a}}$ \\
Copper (ppm) & $2.13 \pm 031^{\mathrm{a}}$ & $2.87 \pm 0.12^{\mathrm{b}}$ \\
Zinc (ppm) & $2.2 \pm 0.10^{\mathrm{a}}$ & $2.07 \pm 0.11^{\mathrm{a}}$ \\
Phosphorous (ppm) & $9.4 \pm 0.92^{\mathrm{a}}$ & $8.93 \pm 0.65^{\mathrm{a}}$ \\
Sulphur (ppm) & $2.07 \pm 0.31^{\mathrm{a}}$ & $1.83 \pm 0.12^{\mathrm{a}}$ \\
Selenium (ppm) & $0.03 \pm 0.01^{\mathrm{a}}$ & $0.02 \pm 0.00^{\mathrm{b}}$ \\
\hline
\end{tabular}

Rows with different alphabets are significantly different while rows with the same alphabet are not significantly different

there was no significant difference between the ash content of the germinated and ungerminated shea kernels. The finding in this study, in relation to the depletion of butter in the germinated kernel, suggests that butter is mobilized, and consumed during the germination process. This implies that for maximum butter yield, all the conditions necessary for shea kernel germination, must be eliminated or reduced to the barest minimum. This is because from this study, a shea kernel processor that processed predominantly germinated feedstock will incur a butter loss of $26.5 \mathrm{Kg}$ per metric tonne of kernel. It was observed in the course of this study that germination of shea kernel occurs when the shea fruit are heaped prior to processing. This may not be noticed without a cursory look at the kernels because when the germination process is no longer sustainable in the heap, the plumule or radicle dies back, dries up and ultimately detached in the process of packing or sort (where it is applicable). The kernel from the external will look unperturbed and intact (Figure 1).

Fatty acid formation due to the hydrolysis of the triacylglycerol in shea butter is one of the major constraints the butter processors strive to minimize in order to produce high quality butter. Table 2 shows that germination increased the FFA by 7 -folds from $0.22 \%$ in the ungerminated to $1.66 \%$, however, FFA values for both the germinated and ungerminated kernel were within grade $A$ according to UEMOA standard. In addition to the fact that UEMOA standard is due for review, the 7-fold increase in ffa means much to a butter refiner that will lose $14.4 \mathrm{~kg}$ butter as soap stock during neutralization stage. Again, very low ffa improves shelf life of butter therefore attracts a premium price. The elevated free fatty value could be attributed to the germination process even though that it is a known fact that hydrolysis could proceed via microbial, enzymatic and autocatalytic pathways. This is because the prompt sterilization of the kernel used in this study must have eliminated the possibility of microbial activities, and the time lag prior to analysis may not be enough for auto hydrolysis. This finding is in line with those reported by other researchers. For example, Ming-Feng et al. (2009) reported that during germination, triacylglycerol stored in seeds are converted into glucose and a variety of essential metabolites. The SV, unsaponifiable matter content, density, PV and anisidine value and total oxidation (Totox) were elevated in the germinated kernel with respect to the ungerminated, while IV decreased. These values generally indicated that germination lowers the quality parameters of shea butter, although in this study, the values expectedly appeared to be small given the fact that the kernels were processed 9 days after picking. This is particularly true for $p$-anisidine and PVs which respectively measure the secondary and primary oxidative states of the butter. These values will definitely increase in the actual current processing conditions in the field. The melting range was also wider. The moisture content was not affected. The rise in SV suggests the presence of lower molecular weight fatty acids, while the decreased IV on the other hand suggests the action of desaturase enzymes.

The influence of germination on shea butter oxidation was evaluated by measuring the PV of the extracted butter. The data show that the PV was significantly $(\mathrm{p}<$ $0.05)$ higher in the germinated kernel $(8.14 \pm 0.59)$ than the ungerminated kernel $(0.10 \pm 0.02)$. This may indicate that germination process encourages lipid oxidation albeit both values fell within acceptable range by the international market. It is therefore envisaged that prolonged germination period may have more deteriorating effect with respect to lipid oxidation on the quality of butter extracted thereof.

The percentage unsaponifiable matter in both the ungerminated $(7.77 \%)$ and germinated $(9.39 \%)$ was significantly $(p<0.05)$ different. This difference in the unsaponifiable matter content could be attributed to the exudation of extractable unsaponifiable metabolite produced during the germination process. It may also be one of the reasons for the wide variation in the range of unsaponifiable matter reported for shea butter. This is because reports in the literature seldom state that condition of the shea kernel employed the work. The composition of the unsaponifiable matter in germinating shea kernel will be investigated to ascertain the source of the increment.

The fatty acid composition of the extracted butter from germinated and ungerminated shea kernels was determined and presented in Table 3. In this study, there was a significant $(P<0.05)$ decrease in the percentage fatty acid composition of the usual six major fatty acids found in shea butter namely [palmitic, (C16:0) stearic (C20:0), oleic (C18:1), linoleic (C18:2) linolenic (C18:3) and arachidonic acids (C18:0)] in the germinated kernel 
compared to the ungerminated. The fatty acids from both samples of butter contained oleic acid (C18:1) and linoleic acid (C18:2) in the highest amount, followed by palmitic acid (C16:0) and stearic acid (C18:0), respectively. After 9 days germination period, the content of linoleic acid (C18:2) decreased from 5.34 to $3.65 \%$ of total fatty acid. These results are similar to the works of Ming-Feng et al. (2009) and Kristina et al. (2007) which suggest the utilization of unsaturated fatty acid in the germination activities of the shea kernel. This altered fatty acid composition due to germination process observed in this study will definitely have impact on other intrinsic properties, applications and health benefits of the butter. Besides the tree-to-tree variation inherent in shea tree and its fruits, processing of germinated shea kernels may be a source variation in the butter quality. This however will depend largely on the ratio of the germinated to the ungerminated kernel in a process batch to be obvious.

\section{Elemental analysis}

In Table 4, save for potassium copper, sodium and selenium which showed significant $(p<0.05)$ variation in other elements analyzed for in the press cake showed no significant difference. The observed differences may be due to the variation in the soil composition within the sample collection area. This indicates that germination had minimal effect on the elemental constituents of the shea kernel.

\section{Conclusion}

Germination contributes significantly to quality depreciation of shea butter especially with respect to FFAs, PV, and the fatty acid composition. The study showed that linoleic acid was mobilized during germination more than the other constituent fatty acids and the elemental composition was not generally affected. The overriding implication of this finding remained that processing shea kernel batch that has high ratio of germinated compared to ungerminated will result in low quality butter with significantly altered fatty acid composition. It is clear therefore that to improve the quality of shea butter prompt sterilization and sorting out, the germinated kernels is needed.

\section{ACKNOWLEDGMENTS}

The authors express their gratitude to the Acting Executive Director, NIFOR, for his support and permission to publish this work, and Mr. George Mbaeyi for the statistical analysis.

\section{REFERENCES}

Bewley JD (1997) Seed germination and dormancy Plant Cell, 9:10551066.

Carette C, Malotaux M, van Leeuwen M, Tolkamp M. (2009). Shea nut and butter in Ghana: Opportunities and constraints for local processing Wageningen University, Wageningen.

Fereidoon Shahidi (2005) Quality Assurance of Fats and Oils Bailey's Industrial Oil and Fat Products, Sixth Edition, Six Volume Set (ed) Fereidoon Shahidi, John Wiley \& Sons, Inc.

lassonova DR, Johnso LA, Hammond EG, Beattie SE (2009). Evidence of an enzymatic source of off flavors in lipoxygenase-null soybeans J. Am. Oil. Chem. Soc. 86:59 -64.

Jøker D (2000) Vitellaria paradoxa Gaertn.f. SEED LEAFLET No. 50, www.dfsc.dk.

Knutzon DS, Thompson GA, Radke SE, Johnson WB, Knauf VC, Kridl JC (1992) Modification of Brassica seed oil by antisense expression of stearoyl-acyl carrier protein desaturase gene. Proc. Natl. Acad. Sci. 89:2624-2628.

Kristina C, Gretchens S, Jillian D, Margaret D, Emile G, Tracy H, Dan W, Nathan S, Paul H, Ming-Feng Y, Yu-Jun L, Yun L, Hui C, Fan C, Shi-Hua S. (2009) Proteomic Analysis of Oil Mobilization in Seed Germination and Post-germination Development of Jatropha curcas J. Proteome. Res. 8(3):1441-1451. DOI: 10.1021/pr800799s.

Munshi SK, Sandhu S, Sharma S (2007). Lipid composition in fast and slow germinating sunflower (Helianthus annuusl) Seeds Gen. Appl. Plant Physiol. 33(3-4):235-246.

Nahm HS (2011). Quality Characteristics of West African Shea Butter (Vitellaria paradoxa) and Approaches to Extend Shelf-Life Graduate School-New Brunswick Rutgers, The State University of New Jersey.

Napier JA (2007). The production of unusual fatty acids in transgenic Plants, Annu. Rev. Plant Biol. 58:295-319.

Nikiema A, Umali BE (2007) Vitellaria paradoxa C.F.Gaertn. In: van der Vossen, H.A.M. and Mkamilo,G.S.(Editors) PROTA14:Vegetable oils/Oléagineux [CD-Rom].PROTA, Wageningen, Netherlands.

Norton T, Sun DW (2008) Recent Advances in the use of high pressure as an effective processing technique in the food industry, Food Bioproc. Technol. 1 (1):2-34.

Official methods and Recommended Practices of The American oil Chemists' Society (1997). 5th edn. AOCS Press, Champaign Illinois.

Official methods of analysis of AOAC International (2010) 18th edn AOAC International, suite 500, 481 North Frederick Avenue, Gaithersburg, Maryland 20877-2417, USA.

Okullo JBL, Omujal F, Agea, JG, Vuzi PC, Namutebi A, Okello JBA, Nyaazi SA (2010). Characterization of Shea butter Vitellaria paradoxa C.F. Gaertn) oil from the shea Districts of Uganda, African J. Food Agric. Nut. Develop. 10(1):2070-2084.

Olaniyan AM, Oje K (2007) Quality Character of Shea butter recovered from shea kernel through dry extraction process, J. Food Sci. Technol. 44 (4):404-407.

PORIM Test Method (2004) Determination of fatty acid composition, MPOB p3.4 Palm Oil Research Institute of Malaysia.

Ted L, (2007) Development, fatty acid composition, and storage of drupes and seeds from the endangered pond berry ( $L$ inderamelissifolia), Biological Conservation, 137:489-496.

Union Economique Monetaire Ouest Africaine (UEMOA) (accessed on 7 March, 2012) Standards for Unrefined shea Butter. http://www.prokarite.org.

Urbano G, Aranda P, VI'Ichez A, Aranda C, Cabrera L, Porres JM, Lo'pez-Jurado M (2004) Effects of germination on the composition and nutritive value of proteins in Pisumsativum, L. Food Chem. 93:671-679. 